\title{
地殼変動検出のためのスタッキング手法の開発
}

\author{
一一東海地域のひずみ計データによるプレート境界 \\ すべり早期検知への適用 \\ 気象庁地震火山部* 宮 岡 一 樹 ${ }^{\dagger}$ \\ 気象研究所地震火山研究部** 横 田崇
}

\section{Development of Stacking Method for the Detection of Crustal Deformation}

\section{-Application to the Early Detection of Slow Slip Phenomena on the Plate Boundary in the Tokai Region Using Strain Data-}

\author{
Kazuki MiYaоKA $^{\dagger}$ \\ Seismological and volcanological Department, Japan Meteorological Agency, \\ 1-3-4 Otemachi, Chiyoda-ku, Tokyo 100-8122, Japan
}

Takashi YокотA

Meteorological Research Institute, 1-1 Nagamine, Tsukuba, Ibaraki 305-0052, Japan

(Received March 16, 2012; Accepted September 28, 2012)

The Japan Meteorological Agency has deployed strain-meters in Shizuoka, Aichi, and Nagano Prefectures, aiming to detect a slow slip phenomenon that is expected to occur just before the anticipated great earthquake of M8 class at the plate boundary. In this paper we propose a stacking method in which data at different stations are added according to the following procedure. First, the observed waveform at each station is normalized by the noise level. Then, the normalized wave form is stacked one by one in the order of the magnitude of the signal to noise ratio, by reversing the polarity considering an assumed source location, if necessary, so as the signal to be all positive. This stacking procedure is stopped when the synthesized signal to noise ratio of the stacked waveform becomes the maximum. Members in the optimum data set that gives the largest signal to noise ratio become different if the location of the assumed source is different. It is shown that the signal to noise ratio of the stacked waveform obtained by this method is enhanced 2.3 times of that of the most favorable individual data. A slow slip event as small as $M_{\mathrm{w}} 5.0$ would be detected if it occurs within the source area of the anticipated Tokai earthquake. We think the stacking method is applicable not only to the strain-meter data, but also to the GNSS and tilt-meter data and such an extension of the method may be effective to detect rising of magma beneath volcanoes.

Key words: Strain meter, Stacking, Tokai earthquake, Slow slip event, SN ratio

* =100-8122 東京都千代田区大手町 1-3-4

** テ $305-0052$ つくば市長峰 1-1

† 現所属: ₹250-0031 神奈川県小田原市入生田 586 神奈川県温泉地学研究所

Hot Springs Research Institute of Kanagawa Prefecture, Iriuda 586, Odawara, Kanagawa 250-0031, Japan

\section{§1. はじめに}

気象庁では, 想定東海地震の直前予知のため, 1976 年からボアホール型のひずみ計を東海地域に設置し [末 廣 (1979)]，その前兆すべりを捕捉するために 24 時間常 時監視を行っている [吉田 (2001)]. 想定東海地震は, 駿河一南海トラフから沈み込むフィリピン海プレートと 


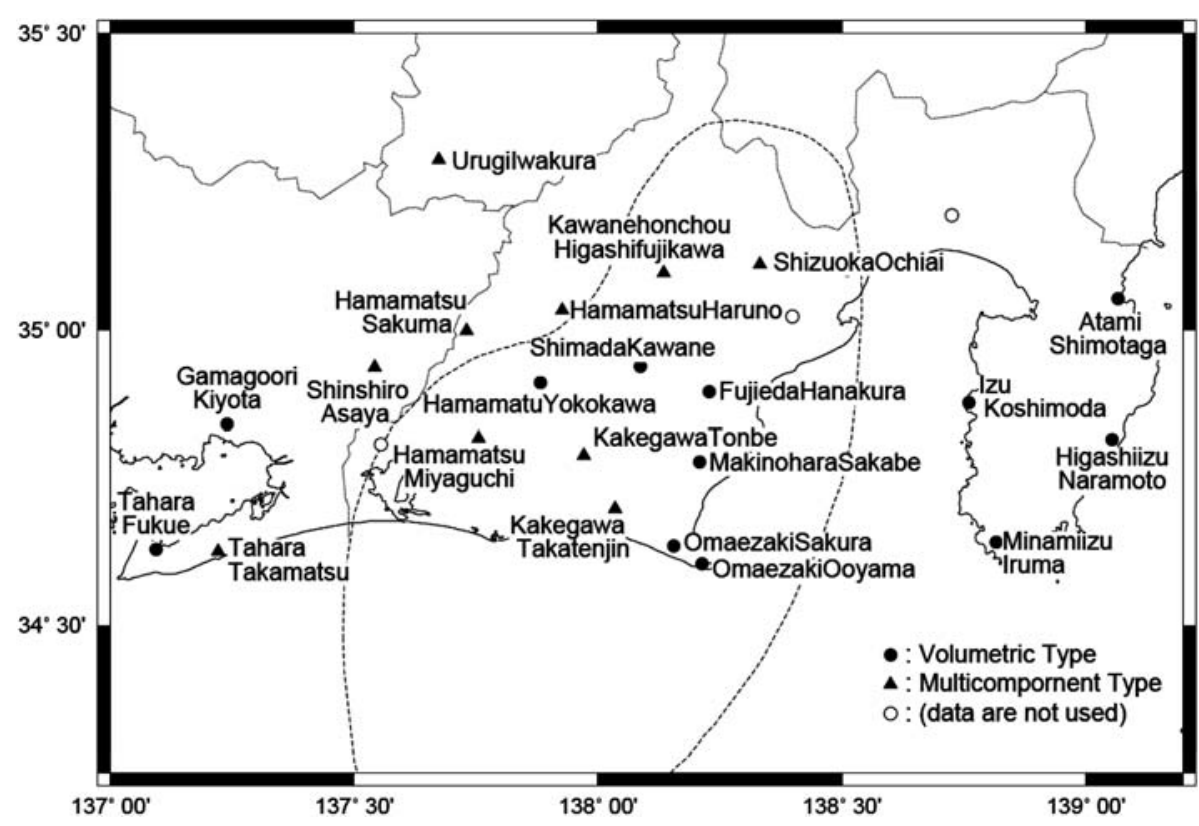

Fig. 1. Location of strain meters in the Tokai region. Circles and triangles represent volumetric strain meters and multi-component strain meters, respectively. The area delineated by a dashed line shows the supposed source region of the anticipated Tokai earthquake. Open circles represent observation sites where their data are not used in this research.

陸のプレートの境界で発生する巨大地震であり, 地震発 生シミュレーション等の研究によると, このような巨大 地震では, その直前に前兆すべりが発生する可能性があ ることが指摘されている [加藤・平澤 (1996), Kuroki et al. (2002)].

想定東海地震は，必ずしも直前予知ができるわけでは ないが，地震発生に繋がる異常現象が観測された場合に はそれを把握し，警戒宣言につなげようということが大 規模地震対策特別措置法の趣旨である．想定東海地震が 突発した場合の対策, 同地震が予知できた場合の対策 等, 想定震源域を含妨災対策の抜本的な見直しが 10 年ほど前になされ， 2003 年 5 月にマスタープランであ る東海地震対策大綱が中央防災会議で決定された [布 村・横田 (2003)]．また，警戒宣言に至ら婸合におい て，ひずみ計等の観測データに異常が検知された場合の 防災対応等についても検討され，新たに東海地震注意情 報等, 東海地震に関連する情報の発表が行われることと なった [上垣内・束田 (2006), 気象庁 (2011a)].

東海地震に関連する情報を的確に発表するには，ひず み計等の観測データの異常の早期検知と, その変化がプ レート境界面上の前兆すべりによるものか否かを速やか に判定することが最重要となる.

このため, 気象庁は, ひずみ計の増設を図り, 2012
年 5 月現在, 静岡県, 愛知県, 長野県に, 体積ひずみ計 16 地点, 多成分ひずみ計 10 地点（静岡県設置の 2 点を 含む）の観測網を展開し (Fig. 1), 更に, 産業技術研究 所整備の多成分ひずみ計を活用して, 愛知県以西の地域 における監視体制の強化を図っている.

体積ひずみ計は概ね 150～250 m の深さに，また多成 分ひずみ計は 400〜800 $\mathrm{m}$ の深さに埋設されており，1 秒サンプリングのデータがリアルタイムで気象庁本庁 （東京都千代田区）に伝送されている。これらひずみ計 は，微弱な前兆すべりを検出することを目的としたもの であり，そのため観測データに，潮汐補正 [石黒・他 (1984)], 気圧補正 [檜皮・他 (1983)], 降水補正 [石垣 (1995), 体積ひずみ計のみ], 地磁気変化補正 [宮岡 (2011), 多成分ひずみ計のみ」を施している.

観測データの異常監視は, 数分から数時間程度の周期 の異常を検出するために，まず伝送されてきた 1 秒サン プリングのデータを基に 1 分サンプリングデータ（1 分 值）を作成し, 次に数時間から数日或いはそれ以上の周 期の変化を検出するために 1 時間サンプリングデータ （1 時間值）を作成する。そして，それぞれの観測デー タに対し一次式でトレンドを除去し, 各地点のノイズレ ベルとの比較によって異常変化の自動検出を図っている [小林・松森 (1999)]. 
気象庁では, これら多成分ひずみ計観測点の増強, 各 種補正方法等の開発・改良によって, 検知能力の改善を 図り，現在，ノイズレベルの小さな観測点では 24 時間 あたりの変化量で $5 \mathrm{n}$ strain $\left(5 \times 10^{-9}\right.$ strain) 程度の微小 な変化を検出できるまでになっている [気象庁 (2010)].

一方, 近年の観測網の強化及び処理技術の発達によ り, プレート境界の巨大地震発生域の深部側で, スラブ の沈み込みに関連する深部低周波地震等が観測されるよ うになった [例えば Obara (2002)]。また，東海地震の 想定震源域の西縁では, 2001 年から 2005 年にかけて長 期的スロースリップイベント (SSE) が発生し [Ozawa et al. (2002), Kobayashi et al. (2005)], その変化量は, 約 5 年間で $M_{\mathrm{w}} 7.1$ 相当の規模のすべり量に相当するもので あった [水藤・小沢 (2009)]. さらに, 長期的 SSE の深 部側の長野県から愛知県にかけての領域では, 概ね半年 に 1 回程度の頻度で, 深部低周波地震の活動に対応し て, 数日程度継続する短期的 SSE が発生していること が分かった [Hirose and Obara (2006), 小林・他 (2006)].

この短期的 SSE を検出するため, 板場・他 (2011) は, 産業技術総合研究所の歪計に防災科学技術研究所の傾斜 計データを統合して用い, グリッドサーチ法によって断 層モデル推定の精度向上を図っている。また中村・竹中 (2004) は, 気象庁のひずみ計で観測された変化量が, プ レート境界面上に仮定した矩形断層がすべった場合にひ ずみ計で観測されるであろう変化量とある幅の範囲で一 致すればその断層がすべったものと見なして, 同じくグ リッドサーチ法ですべりの位置とすべり量を求める手法 を開発した。この手法は, 東海地震の前兆すべりの捕捉 を目的としたものであったが, 短期的 SSEの解析にお いて, 現在, 気象庁で用いられている.

たたし,これらは深部低周波地震活動の発生をトリ ガーに，ひずみ計などに現れた変化を見直しながらゆっ くりすべりの場所や大きさを推定しょうとするもので, 基本的に，その早期検知を目指したものではない.

本論では前兆すべりの早期検知を目的とする手法を提 案する。このためには, ひずみ計の SN 比を向上させ, すべりの初期の段階での小さなシグナルを際立たせる必 要がある.

プレート境界でのすべりによるひずみの時間変化は, すべりの場所が, 観測点との相対的な位置関係が変わっ てくるほどに大きく変化しなければ, 極性は別にして観 測点間で相似である。このことを基礎に，多点のひずみ 計データを足し合わせることで SN 比を高めるというこ とが, ここで提案する手法のエッセンスである。

第 2 章でその手法の詳細（以下, スタッキング法と呼 称）を紹介し, 第 3〜 5 章では東海地域におけるプレー
卜境界すべり（前兆すべりや短期的 SSE）の検出にそ れを適用して性能の評価を行う。

\section{§2. スタッキング法について}

微弱な信号の検出能力を高める方法として, 地震波の アレイ処理がある。この場合, 地震波の到来方向を仮定 した上で，速度構造を基に各観測点における到着時刻差 を加減して波形をスタッキングすることで SN 比を改善 させている。

本論で提案するひずみ変化の SN 比を高める処理は, プレート境界すべりを仮定して，各観測点でのひずみ変 化が, 全て伸び方向（十方向）となるように, 極性が逆 のものは反転させた上で波形をスタッキングするという 手法である. Fig. 2 にその概念図を示した，複数の波形 のスタッキングによって SN 比の向上を図るという点に おいては地震波のアレイ処理と同じであるが, 本手法に は以下のような特徴がある。その一つは, 観測点毎にノ イズレベルが大きく異なることから，スタッキングの際 に，ノイズの大きさを考慮してウェイトをつけること. そしてもう一つは, SN 比の大きな観測点だけを選別し てスタッキングすることにより, その効果の極大化を図 ることである。

プレート境界での断層すべりを考えたとき，すべりの 位置および領域が時間とともに変わらず，単にすべり量 が増していくという仮定をおくと，各観測点のひずみの 時間変化は, 極性は別として相似となる.したがって, 各観測点のノイズが互いに無相関であれば, 極性を考慮 して波形をスタッキングすることによりシグナル成分が 加算される一方でノイズは互いに打ち消し合うので, $\mathrm{SN}$ 比の高い合成波形（以下スタッキング波形）が得ら れることになる。実際にはプレート境界面上のすべりは 発生域の移動や拡大を伴うと考えられ, 単純に波形が相 似になるとはいえない.この問題については第 4 章の観 測事例及び第 5 章の考察のところで検討する.

以下, 東海地域のフィリピン海プレート上面で発生す るゆっくりすべり（前兆すべり，短期的 SSE）を例に とって, スタッキング法の考え方及び解析の手順を説明 する。ここでは, 気象庁および静岡県が東海地域に設置 しているひずみ計のうち, 観測点特有の不規則な変化の 発生頻度が高い観測点は除いて, 体積ひずみ計 12 点と 多成分ひずみ計 10 点のデータを用いている，なお，同 一観測点で複数の成分を持っている多成分ひずみ計で は，それぞれの成分が独立の観測值であるとしてスタッ キングする。本論文では同一観測点の各成分のデータに ついても,「各観測点のデータ」と呼称している.した がって, 計 72 観測点のデータを用いることになる (Table 


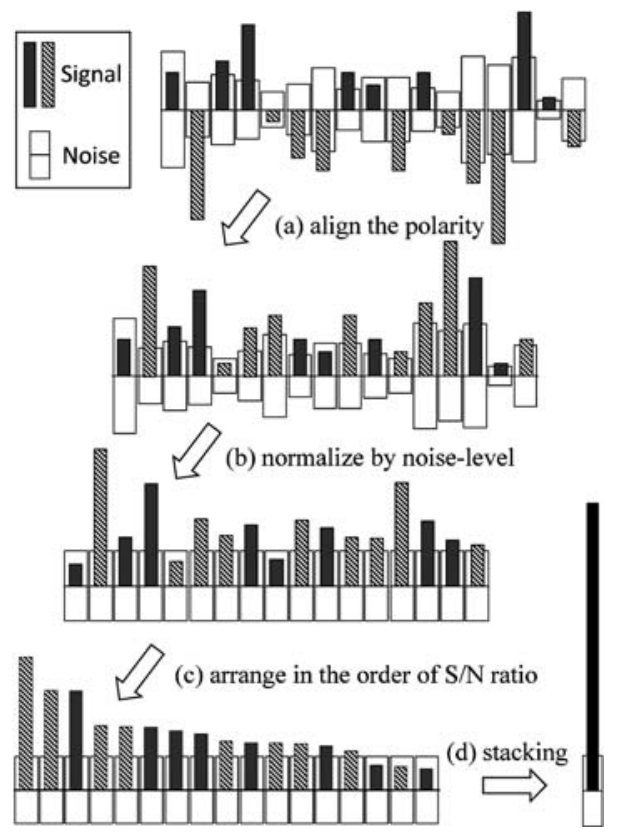

Fig. 2. Schematic diagram of the stacking method. Black, hatched, and white bars indicate positive signal change, negative signal change, and noise, respectively. (a) Changing the sign of the signal when the polarity is negative. (b) Normalizing the signal by the noise level. (c) Arranging the data in the order of the signal to noise ratio. (d) Stacking the data.

\section{1).}

スタッキング波形を求めるにあたっては，まず，フィ リピン海プレート境界面上にグリッドを設定し，各グ リッド上に想定した断層がすべった場合の，各観測点に おけるひずみの理論変化量を, 半無限弾性媒質を仮定し Okada (1992) を用いて求めておく.ここで, 断層の位置, 走向，傾斜は Hirose et al. (2008) によるフィリピン海プ レートの形状モデルを基に定め，また上盤に対するフィ リピン海プレートの進行方向は Heki and Miyazaki (2001)によって N55W と仮定して，これらを基にすべり 角を計算した。体積ひずみ観測点については, こうして 計算される体積ひずみ変化を，また多成分ひずみ観測点 ではそれぞれの観測成分の方位における線ひずみ変化を 理論シグナル值として用いる。

なお，ボアホールタイプのひずみ計では，周囲の岩盤 とのカップリング状況などによって，観測されるひずみ 変化が広域のひずみ変化を正しく反映していない可能性 がある.これについては上垣内・他 (1999) が, 潮汐変化 や遠地の地震波形などを用いて観測点毎の応答係数を求
めているので, その応答係数を理論シグナル值の計算に 反映させている.

\section{1 ひずみ波形のスタッキング}

分散が $\sigma^{2}$ の母集団から $m$ 回サンプリングしたとき, それらの和の分散は $m \sigma^{2}$, 標準偏差は $\sqrt{m} \sigma$ となる. このことから，ノイズ成分の分散がそれぞれ $\sigma^{2}$ である 同時間带の $m$ 個の独立な波形を重ね合わせたスタッキ ング波形のノイズの分散は $m \sigma^{2}$, その標準偏差は $\sqrt{m}$ бになると推定される。一方, シグナル成分については, 各波形のシグナル強度が同等であるとすると, スタッキ ング波形の振幅は $m$ 倍となるので, $\mathrm{SN}$ 比は $\sqrt{m}$ 倍に 向上すると期待される.

ただしこの場合，各波形データのノイズは全て，その 分散が $\sigma^{2}$ で等しく, シグナルの強度も同じであること が前提となる，実際のひずみ観測では各観測点でのノイ ズレベルはまちまちであり，1桁以上も異なる場合があ る。その状況は, 2011 年 8 月から 11 月の期間の 1 時間 值を用いた時の，24 時間階差の標準偏差を示した Fig. 3 に見ることができる（以下，本稿に扔けるノイズレベル にはこの值を用いる).ノイズレベルにこのような大き な差があるデータをスタッキングするにあたり，その前 処理として各観測点のノイズレベルによって波形振幅の 規格化を行って, 各観測点データにウェイトをつける. 観測点 $i$ におけるウェイト $w_{i}$ は以下のように表される.

$$
w_{i}=\frac{n_{s}}{n_{i}}
$$

ここで, $n_{i}$ は観測点 $i$ に抒けるノイズレベルで単位時間 あたりの変化量の標準偏差, $n_{s}$ はウェイトを無次元化 するための任意の定数で, 例えば, 全観測点のノイズレ ベルの平均值などを取ればよい，このような規格化を行 うことにより，複数の観測点のひずみデータをスタッキ ングした場合, 個々の観測データのノイズが互いに無相 関であれば, ノイズの打ち消し合いの効果が得られるは ずである。

このとき，プレート境界のある場所 $j て ゙$ 発生したすべ りを検知するためのスタッキング波形 $A_{j}(t)$ は以下の式 で表される。

$$
A_{j}(t)=\sum_{i=1}^{m} Y_{i}(t) c_{i j}
$$

ここで $Y_{i}(t)$ は観測点 $i$ における時系列変化, $c_{i j}$ はスタッ キングする際に乗ずる倸数（以下，スタッキング倸数） で，あらかじめ理論計算しておいた観測点 $i$ に扔けるひ ずみ変化の極性 $p o l_{i j}$ とウェイト $w_{i}$ の積で表される.

$$
c_{i j}=\operatorname{pol}_{i j} w_{i}=\operatorname{pol}_{i j} n_{\mathrm{s}} / n_{i}
$$

(2) 式は，ノイズレベルで規格化した各観測点のデータ を、ひずみ変化の極性を同じにしてスタッキングするこ 
Table 1. Sensor type and sensor direction for the multi-component type.

\begin{tabular}{|c|c|c|c|}
\hline $\begin{array}{l}\text { Station } \\
\text { ID }\end{array}$ & Station Name & $\begin{array}{c}\text { Sensor } \\
\text { Type }\end{array}$ & Sensor Direction \\
\hline GMG & Gamagoori Kiyota & Volumetric & \\
\hline YKK & Hamamatu Yokokawa & Volumetric & \\
\hline SMD & Shimada Kawane & Volumetric & \\
\hline OYM & Omaezaki Ooyama & Volumetric & \\
\hline HNK & Fujieda Hanakura & Volumetric & \\
\hline $\mathrm{IZK}$ & Izu Koshimoda & Volumetric & \\
\hline HGI & Higashiizu Naramoto & Volumetric & \\
\hline SKR & Omaezaki Sakura & Volumetric & \\
\hline MKN & Makinohara Sakabe & Volumetric & \\
\hline ATM & Atami Shimotaga & Volumetric & \\
\hline MNI & Minamiizu Iruma & Volumetric & \\
\hline FKE & Tahara Fukue & Volumetric & \\
\hline $\mathrm{TNB}(1-4)$ & Kakegawa Tonbe(1-4) & Multi & $177,87,42,132$ \\
\hline $\operatorname{SKM}(1-4)$ & Hamamatsu Sakuma(1-4) & Multi & $135,45,0,90$ \\
\hline MYG(1-4) & Hamamatsu Miyaguchi(1-4) & Multi & $4,94,229,139$ \\
\hline $\operatorname{HRN}(1-4)$ & Hamamatsu Haruno(1-4) & Multi & $2,92,47,137$ \\
\hline $\operatorname{HFK}(1-4)$ & Kawanehonchou Higashifujikawa(1-4) & Multi & $1,136,91,46$ \\
\hline OCA $(1-8)$ & Shizuoka Ochiai(1-8) & Multi & $252,342,27,117,252,342,27,117$ \\
\hline TTJ(1-8) & Kakegawa Takatenjin(1-8) & Multi & $198,288,333,63,198,288,333,63$ \\
\hline IWK(1-8) & Urugi Iwakura(1-8) & Multi & $209,299,344,74,209,299,344,74$ \\
\hline ASY(1-8) & Shinshiro Asaya(1-8) & Multi & $165,255,300,30,165,255,300,30$ \\
\hline TKM(1-8) & Tahara Takamatsu(1-8) & Multi & $65,155,200,290,65,155,200,290$ \\
\hline
\end{tabular}

とを意味している， $m$ はスタッキングする波形の総数 である。

この際の重要なポイントは，スタッキングするための 観測点の選別方法である.

各観測点におけるひずみ波形 $Y_{i}(t)$ にはシグナル成分 とノイズ成分が含まれていると考え，それぞれを $S_{i}(t)$, $N_{i}(t)$ とおくと， $Y_{i}(t)$ は以下のように表すことができる.

$$
Y_{i}(t)=S_{i}(t)+N_{i}(t)
$$

(4) 式を(2) 式に代入すると,

$$
A_{j}(t)=\sum S_{i}(t) c_{i j}+\sum N_{i}(t) c_{i j}
$$

となる。このとき, $m$ 個のデータをスタッキングした 波形 $A_{j}(t)$ に含まれるシグナルのノイズに対する比 $S N_{j}$

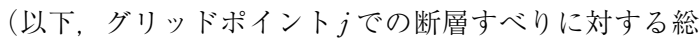
合 SN 比, 略して総合 SN 比と呼ぶ）は次のように表さ れる。

$$
S N_{j}(t)=\frac{\sum_{i=1}^{m} S_{i}(t) c_{i j}}{\sum_{i=1}^{m} N_{i}(t) c_{i j}}
$$

ここでノイズ $N_{i}(t)$ の振幅と標準偏差は時間によって変 わらず，また観測点間で相関がないとすると， $S N_{j}(t)$ は 以下の様に表される.

$$
S N_{j}(t)=\frac{\sum_{i=1}^{m} S_{i}(t) \operatorname{pol}_{i j} n_{s} / n_{i}}{n_{s} \sqrt{m}}=\frac{\sum_{i=1}^{m} S_{i}(t) p o l_{i j} / n_{i}}{\sqrt{m}}
$$

さて，問題は $m$ の值をどう決めるかである，すべての 観測点をスタッキングしてしまうと, シグナルが非常に 小さく、ノイズレベルに埋まるような観測点も含まれる ことになる。そのようなデータを加えても総合 SN 比の 向上は望めない.したがって, 観測点の選別にあたって 重要なことは, 総合 SN 比が最も大きくなるような組合 せを選び出すことである，本論文で提案するスタッキン グ法のエッセンスは, 理論シグナル值をノイズレベルで 規格化した值の大きな観測点から順に波形をスタッキン グしていき, その都度, 総合 SN 比を調べて, 最も大き な総合 SN 比を与える組合せを選び出すことにある. な お，この手法に扔いて，スタッキングする観測点の順番 や組み合わせは, どのグリッド点での断層すべりを想定 するかによって変わってくる.

以下で，この手続きを，想定震源域内のフィリピン海 プレート境界面上に想定した断層（Fig. 5 の矩形）です ベりがあったとしたときを例にとって説明する。

Fig. 4 には，ノイズレベルで規格化した理論シグナル 值を棒グラフで示した，上から，その值の大きな順に並 ベている。またそれらを順番にスタッキングしていった 


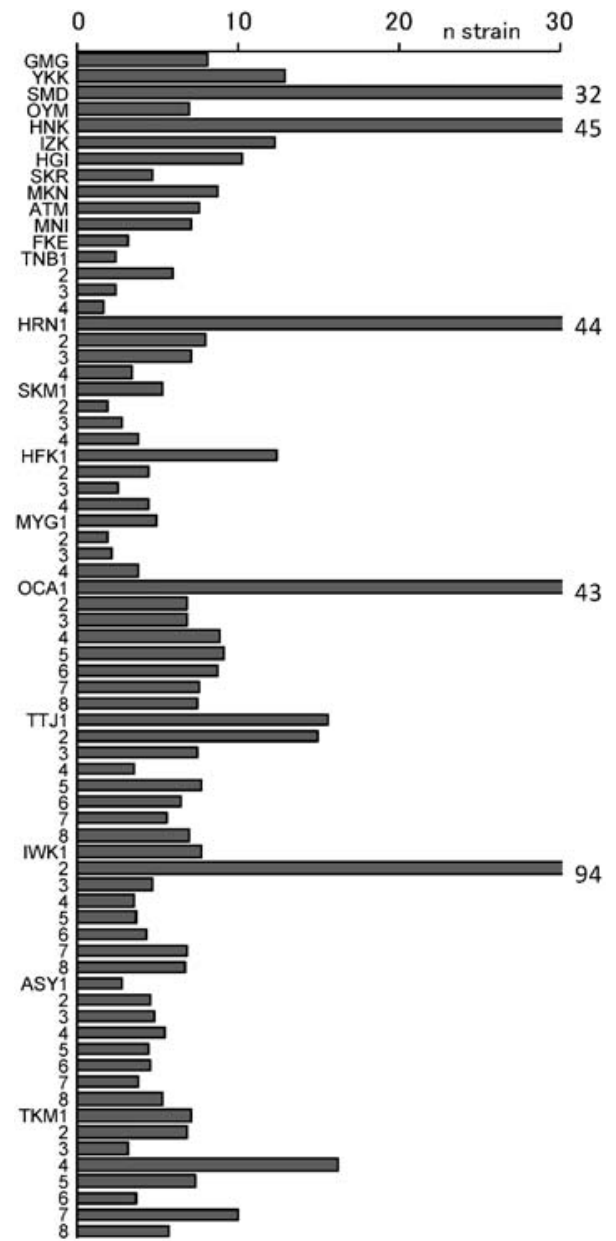

Fig. 3. Magnitude of the noise level of the data at each observation station.

場合の総合 SN 比の変化を折れ線グラフで示した。 ノイ ズが観測点間で無相関であれば， $m$ 個の波形をスタッ キングした場合のノイズレベルは，(7) 式に示すように $n_{s} \sqrt{m}$ となる。この場合のスタッキング数 $m$ に対する 総合 SN 比の変化は Fig. 4 の破線の様になる. しかし, 実際のノイズには潮汋補正残差などの同相ノイズが含ま れている場合があり，波形を足し合わせていったとき に，必ずしも (7) 式の通りにはならない。このため, ス タッキングする毎にスタッキング波形のノイズレベルを 調べて, 総合 SN 比の值を確認する必要がある.

まず，(6)式の $m$ を 2 とした場合を考える，分子のシ グナル成分は，ノイズレベルで規格化した後の值が大き な上位 2 つの理論シグナル值の和である。分母のノイズ 成分は，1番目と 2 番目の観測点のスタッキング波形の ノイズレベルであり, 各観測点のノイズレベルを算出し

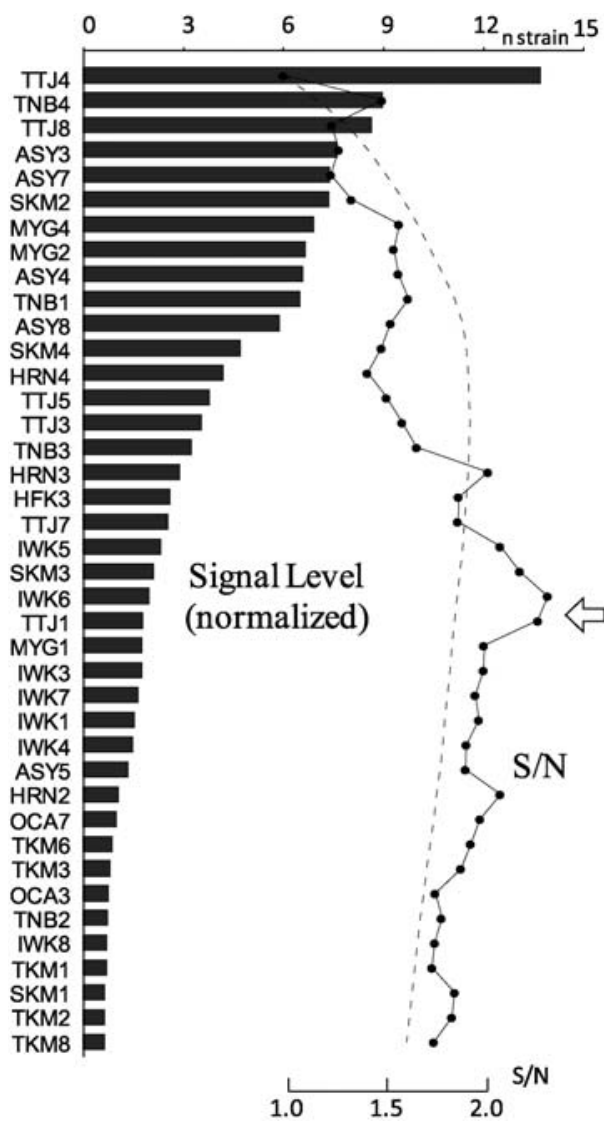

Fig. 4. An example demonstrating the stacking method. Bars represent amplitudes of the signal normalized by the noise level. A solid line shows change in the synthesized signal to noise ratio when stacked data is increased one by one. A white arrow indicates the optimum number of the station for the stacking. A broken line indicates the synthesized signal to noise ratio that is expected when the noise is white and not correlated to each other.

たときと同じ方法で調べた，スタッキング波形の 24 時 間階差の標準偏差である。このノイズ成分に対するシグ ナル成分の比が，2番目までスタッキングした時の総合 SN 比である. 以降, スタッキングする波形を増やして いく毎に逐次, 同様の方法で総合 SN 比を求めていく.

このように順次, 波形をスタッキングしていったとき の総合 SN 比の変化を示したのが Fig. 4 の実線である. 最も SN 比が大きくなる組み合わせ（スタッキング数 $m$ ）を採用するとすれば，この例では 22 番目（図中の 矢印）までとなる。

なお，ここでは断層サイズを $15 \mathrm{~km} \times 15 \mathrm{~km}$ ，すべり 


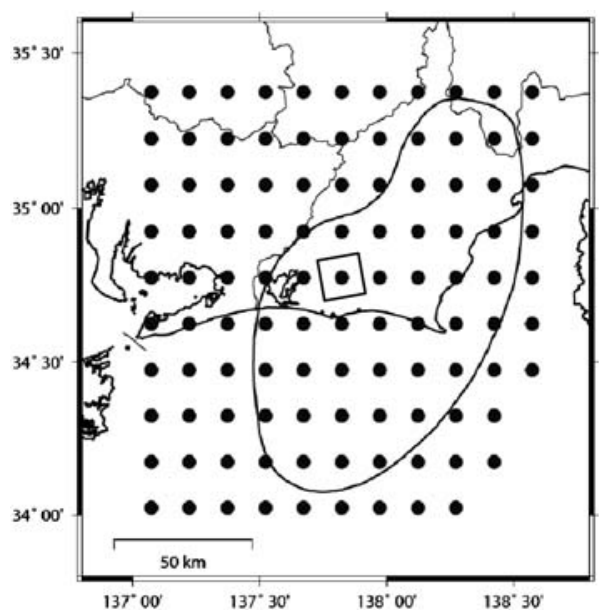

Fig. 5. A set of 106 grid points in the Tokai region which is used to watch occurrence of a slow slip event. A rectangle area shows the supposed fault plane put at the grid.

量を $0.6 \mathrm{~cm}$ とした場合（ $M_{\mathrm{w}} 5.0$ 相当）について総合 $\mathrm{SN}$ 比を求めている。すべり量の大きさに依って理論シグナ ル值の大きさや総合 SN 比の值は変わるものの, 観測点 毎のシグナルの大小関係は変わらないことから, 最大の 総合 SN 比を与える $m$ はすべり量に依ることなく求め ることができる。このような手続きを，プレート境界面 上に設定したグリッド上のすべての断層に対して, 予め 行っておき，それぞれの断層についてスタッキングする 観測点の組み合わせとその順番を求めておくことにな る。なお，断層サイズを大きく変えると，後述の様に， 最大の総合 $\mathrm{SN}$ 比を与える $m$ が変わってくることもあ る.

上記の様な作業により, (2) 式で示すスタッキング波 形 $A_{j}(t)$ を作成するために必要なパラメータ（スタッキ ング数 $m$ の最適值とそれぞれの観測点データに対する スタッキング係数）が得られたことになる.

\section{2 スタッキング波形を用いたゆっくりすべりのモ ニタリング}

Fig. 5 に, 東海地震の想定震源域及びその周辺での ゆっくりすべりの発生を捕捉するにあたって設定したグ リッドの例を示す。ここでは, 緯度, 経度 $0.15^{\circ}$ 毎に 15 $\mathrm{km} \times 15 \mathrm{~km}$ の断層を設定している。この設定した断層 全てについて，2.1節の方法により，スタッキングのた めのパラメー夕を準備しておき, 毎時得られる各観測点 のデータを基に，(2) 式を用いて全グリッドにおけるス タッキング波形を作成し, モニタリングしていくことに なる。スタッキングした波形の異常検出には, 小林・松
森 (1999) が個別の観測点データについて行なった自動 検出の方法を適用している.

本論で提案するスタッキング法は, 小さな異常変化が 現れた時点で, それを早期に, 確実に検知することを目 的としており，実際に異常が検出された場合には，すべ り量やモーメント量などについて, 別途, 詳細な解析を 行なう必要がある。ただし，スタッキング波形のモニタ リングからだけでも, すべりの候補域や断層すべりの モーメント量の大まかな見積もりを行なうことが出来る.

すべり位置については, スタッキング波形が大きな異 常変化を示すグリッドがその候補となる，なお，本当は そこですべっていないグリッドにソースがあったと想定 してスタッキングした波形にも変化が現れる場合がある が,これについては第 5 章で考察する.

また，断層すべりのモーメント量については，以下に 示すように, スタッキング波形の変化量からおおまかな 推定が可能である.

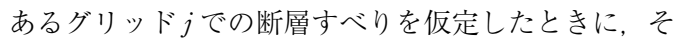
のモーメント $M_{0}(c a l)$ と, 各観測点におけるひずみ変化 量 $S_{\mathrm{i}}(c a l)$ とは比例する。すなおち

$M_{\mathrm{o}}(\mathrm{cal})$ \&s $S_{\mathrm{i}}(\mathrm{cal})$

これから，各観測点のひずみ変化量にそれぞれのスタッ キング係数を乗じて重ね合わせたスタッキング波形の変 化量 $A_{\mathrm{j}}(\mathrm{cal})\left(=\sum S_{\mathrm{i}} c_{\mathrm{ij}}\right)$ も，モーメント量と線形関係にあ ることがわかるので, スタッキング波形の変化量から モーメント量に換算する比例係数を $k_{\mathrm{j}}$ とおくと,

$$
M_{\mathrm{o}}(c a l)=k_{\mathrm{j}} A_{\mathrm{j}}(\mathrm{cal})
$$
となる。

ここで, 観測されたスタッキング波形の変化量を $A_{\mathrm{j}}(o b s)$ とすると, モーメント量 $M_{\mathrm{o}}(o b s)$ は以下のように 求められる.

$$
\begin{aligned}
M_{\mathrm{o}}(o b s) & =k_{\mathrm{j}} A_{\mathrm{j}}(o b s) \\
& =M_{\mathrm{o}}(c a l) / A_{\mathrm{j}}(c a l) A_{\mathrm{j}}(o b s)
\end{aligned}
$$

なお，実際にすべった範囲は予め設定した候補断層面 と必ずしも一致するわけではないので, 推定されたモー メント量は概算值となる。ただ，スタッキング波形の 振幅をひずみ量の単位 (strain) ではなく, モーメント $(\mathrm{Nm})$ に換算して示すこともできるので, モニタリング 上, 容易にモーメント量あるいはそれに基づいて $M_{\mathrm{w}}$ を 推定できることのメリットは大きいと考えられる.

\section{3 模擬波形によるスタッキング}

次に，ひずみ波形のスタッキングによって微小なシグ ナルが際立たせられるようになることを, 模擬データを 用いて示す (Fig. 6). この例では, 想定震源域内のフィ リピン海プレート境界面上の断層（Fig. 5 の矩形）で, 図の最上段に示したような時間変化をする $M_{\mathrm{w}} 5.0$ 相当 
のすべりが生じたと仮定した．以下の波形は，この場合 に計算される各観測点でのひずみ変化量を，プレート境 界すべりや大きな気象擾乱などのない期間のデー夕 （2011年 10 月 30 日～11 月 5 日）に重ね合わせたもので ある. 各観測点の変化が上向きとなるように必要に応じ て極性を反転させ， SN 比の大きなものから順に並べて 表示してある. 最下段はこれら 15 観測点のデータによ るスタッキング波形で, 振幅を $2 / 5$ 倍にして表示した。 単独では上位 5 点程の観測点でわずかに変化しているこ とが涊められる程度であるが，スタッキングした波形は

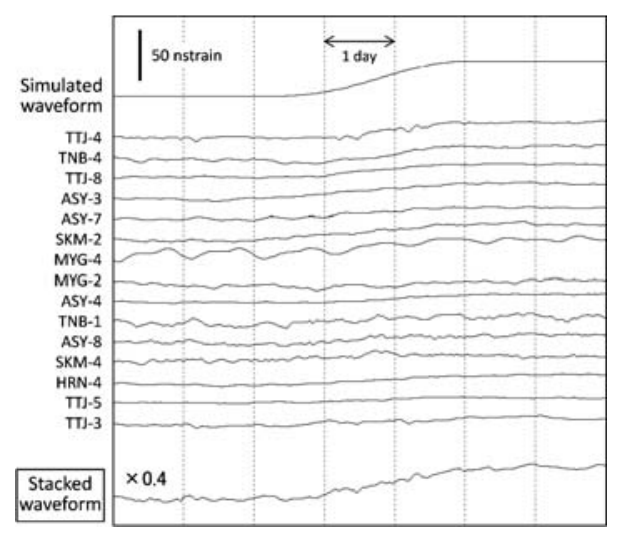

Fig. 6. An illustration showing the effect of the stacking method. The top trace shows the waveform of an $M_{\mathrm{w}} 5.0$ slow slip event that is supposed to occur at a point within the source region of the anticipated Tokai earthquake. The waveform at each station is the superposition of the signal generated by the slow slip and the noise that was observed in the period from October 30 through November 5, 2011. The bottom trace shows the stacked waveform where the actual amplitude is reduced to two fifths.
目視の範囲でもシグナルが現れていることが認識でき, $\mathrm{SN}$ 比が大幅に改善されていることがわかる. 改善の程 度を評価する目安として, 最良の観測点の SN 比とス タッキング波形の総合 SN 比の比をとると, 2.1 となる.

\section{§3. 前兆すべり検知への適用}

スタッキング法を開発した目的は, 固着域を含めたプ レート境界でのゆっくりすべりの検出能力を高めること である。 その有効性を確認するために, 想定震源域とそ の周辺に設けた106のグリッド (Fig. 5)について, ス タッキング波形の総合 SN 比と, 最良の観測点の SN 比 との比較を行った。 その結果, スタッキング波形の総合 SN 比は, Fig. 5 に示した調査領域全体では平均で 2.0 倍, 想定震源域と短期的 SSE 発生領域に限れば 2.3 倍に 改善されており，より小さなすべりを検知出来ることが 期待される.さらに, 従来の小林・松森 (1999) の方法で 自動検知しようとする場合, 最も SN 比の良い 1 観測点 だけではゆっくりすべり発生の確証は得られにくい他, 複数観測点のデータを用いる中村・竹中 (2004)などの 方法ですべり位置や規模の情報を得ようとする際には, $\mathrm{SN}$ 比の低い観測点の変化量を個別に読み取る必要があ るため, ゆっくりすべりの早期検知という実用的な観点 から見たとき, スタッキング法の効果は大きいといえる.

次にスタッキング法を用いたときのプレート境界すべ りの検出限界について検討する。前兆すべりや短期的 SSEのすべり始めの捕捉を目的としていることから, 検出しうる 24 時間あたりのすべりの大きさを調べた.

Fig. 7 は, スタッキング波形の 24 時間変化量の総合 SN 比が 2.0 , もしくは 3.0 を超えるときの $M_{\mathrm{w}}$ を検知限界と した場合に，各グリッドポイントでのすべりで検知しう る最小 $M_{\mathrm{w}}$ の分布を示したものである. 総合 SN 比が 2.0 のシグナルを検知限界とした場合では, $M_{\mathrm{w}} 5.0$ のコン ターが想定震源域の陸域とその西側の領域および, 想定
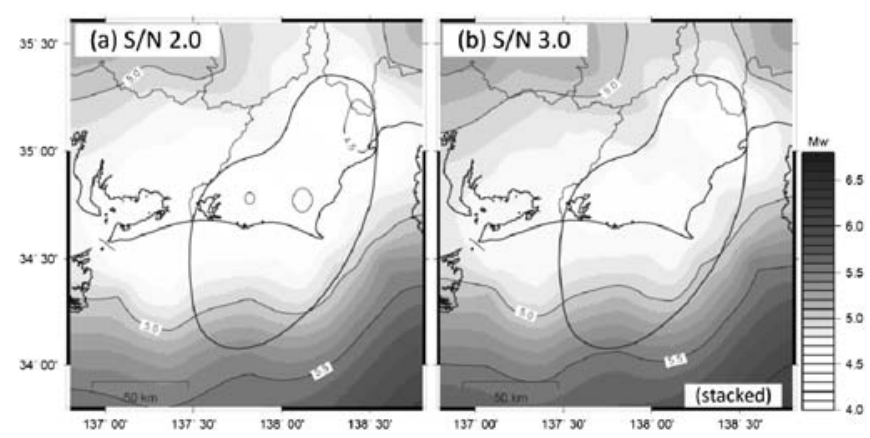

Fig. 7. Spatial distribution of the smallest slow slip event (the lower limit of the moment magnitude) when a criterion is set that the synthesized signal to noise ratio is (a) 2.0 or (b) 3.0. 

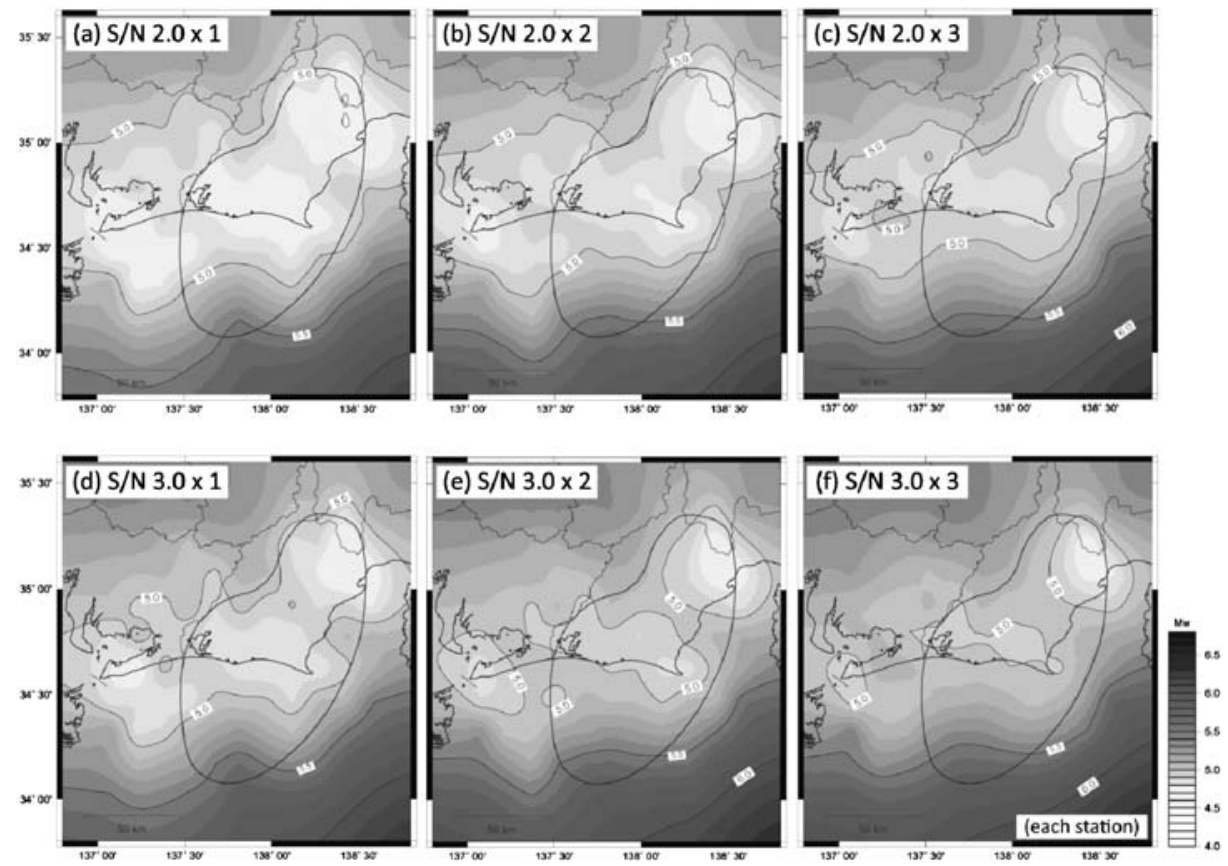

Fig. 8. Spatial distribution of the smallest slow slip event (the lower limit of the moment magnitude) when a criterion is set that the signal to noise ratio is 2.0 at (a) one, (b) two, and (c) three data. (d), (e), and (f) are the same as (a), (b), and (c) except that the signal to noise ratio is 3.0.

震源域の海域の大半をカバーしており, 24 時間に $M_{\mathrm{w}} 5.0$ 相当のプレート境界すべりがこの範囲で生じれば，それ を検知できることがわかる (Fig. 7 (a)). 想定震源域内の 陸から離れた領域についても，24 時間あたり $M_{\mathrm{w}} 5.3$ 程 度以上のすべりであれば検知可能である. 総合 SN 比 3.0 を検知限界とした場合でも，想定震源域の半分以上で $M_{\mathrm{w}} 5.0$, 全域でも $M_{\mathrm{w}} 5.5$ のすべりがあれば捕捉できるこ とが見てとれる (Fig. 7 (b)).

比較のために, 個別観測点での SN 比 2.0 もしくは 3.0 を検知基準とし，これを越える観測点数がそれぞれ 1 点, 2 点, 3 点の場合について, 検知しうる最小 $M_{\mathrm{w}}$ の 分布を Fig. 8 に示した. SN 比 2.0 を越える観測点が 1 点とした場合 (Fig. 8 (a)) でも， 24 時間で $M_{\mathrm{w}} 5.0$ 相当の すべりを検知できる範囲は, スタッキング法の方がやや 広いことが見てとれる。ここで注意すべきは，1点だけ の変化からではプレート境界すべりであるか否かの判断 はできないことである. SN 比 2.0 を越える観測点が 2 点あるいは 3 点で検出されることを条件とした場合, ス タッキング法との差はさらに大きくなる (Fig. 8 (b), (c)). $\mathrm{SN}$ 比 3.0 を検知基準とした場合の比較でも傾向は同じ である (Fig. 8 (d)〜 (f)). SN 比 2.0 を超える観測点が 3 点 もしくは 3.0 を超える観測点が 3 点の場合について, ス
タッキング法と比べると（Fig. 7 (a) と Fig. 8 (c), Fig. 7 (b) と Fig. 8 (f) の比較), 検知能力の向上は $M_{\mathrm{w}}$ 換算で, いずれも概ね 0.3 となる.

\section{§4. 短期的 SSE の観測事例による検証}

スタッキング法の有効性を示す事例として, 東海地方 において観測されている短期的 SSEについての解析結 果を示す.

小林・他 (2006) は, 気象庁による一元化カタログで低 周波地震の震源が帯状に分布している長野県から愛知県 にかけての領域を, A, B C C 3つの領域に分けている.

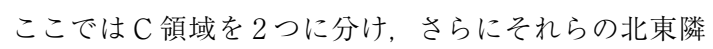
と南西隣に 1 点ずつ加えた計 6 点にグリッドを設定し た. 各グリッドポイント（1)〜 (6)）には $15 \mathrm{~km} \times 15 \mathrm{~km}$ の断層を仮定した. Fig. 9 に，2011 年 7 月に観測された 深部低周波地震の震央とともに, 各グリッドポイントの 断層矩形を示す. 短期的 SSE が深部低周波地震の震源 域で発生したとすると, それはグリッドポイントの(4)と (5)のところにあたる。またそのすべりの発生時期は低周 波地震の時空間分布図 (Fig. 9 (c)) から, (4)では期間の前 半 (7月 26 日〜 28 日), (5)では期間の後半（7月 29 日 〜31日）であったと推測される. 


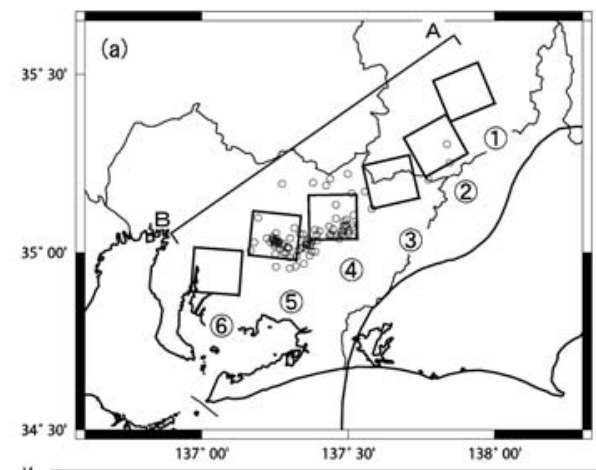

(b) $2012 / 07 / 22 \sim 08 / 05$
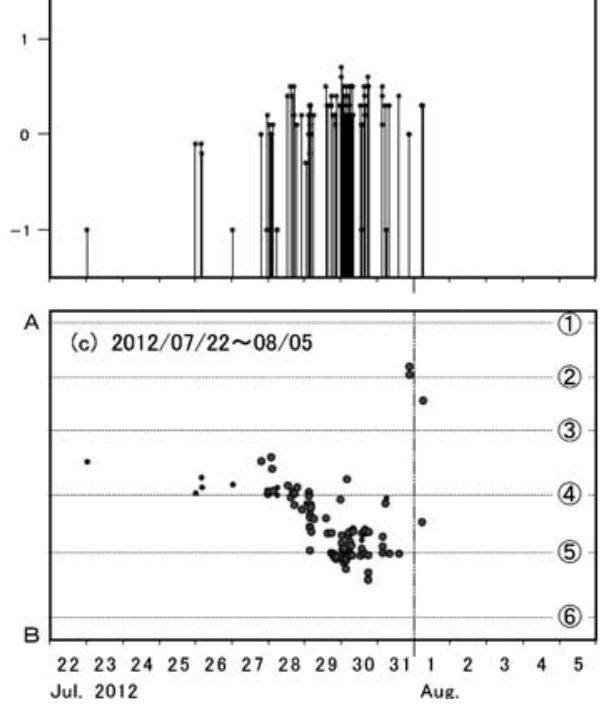

Fig. 9. (a) Squares with numerals indicate a set of faults where a slow slip is supposed to occur. Circles represent epicenters of low-frequency earthquakes that occurred during the short-term slow slip event in July 2011. (b) Magnitude-time diagram of the low-frequency earthquakes, and (c) their time-space distribution projected to the direction $\mathrm{A}-\mathrm{B}$ in the top map.

最初に，スタッキングによる SN 比向上の効果を確認 する. Fig. 10 に，すべり場所を(4)あるいは(5)に仮定し たときのスタッキング波形と，それぞれの場合のスタッ キングに用いたオリジナル波形を示した。オリジナル波 形の振幅は各観測点のノイズレベルで規格化し, さらに イベント発生前 1 週間のトレンドを基に, 1 次式でトレ ンド成分を補正している。ここには SN 比が大きなもの について表示した。なお最上段のスタッキング波形は振 幅を2/5にしてある。

(4)においては, 各観測点のデータでも 7 月 27 日から
29 日にかけて, 短期的 SSE に伴うわずかなひずみ変化 が見えているが(Fig. 10 (a)), スタッキング波形（最上 段）では，その変化がより明暸である。最も SN 比が高 い観測点と比べても，スタッキング波形の SN 比は約 2 倍改善されている。また(5)では，7月 29 日から 31 日に かけて, 各観測点で比較的はっきりとした変化が認めら れるが (Fig. 10 (b)), スタッキングした波形（最上段） ではその変化がいっそう明瞭となっている. (4)と同様, $\mathrm{SN}$ 比の改善は約 2 倍である. なお, どちらの場合も, 各観測点の変化の極性は，はっきりと目視で識別できる ものについては，モデル計算から期待されるものと一致 している.

早期検知に関するスタッキングの効果を見るために, 短期的 SSEの自動検知の基準を, ノイズレベルの 2 倍 とした場合の検知日時を求め, スタッキング波形と各観 測点の波形を比較してみた。 その結果, 個別で最も早い 観測点での検知は 27 日 23 時であったのに対し，スタッ キング波形では 27 日 13 時であるので, 10 時間早く検 知出来たことになる。今回のイベントの直前に降雨があ り, Fig. 10 (a)のスタッキング波形にやや右上がりのト レンドが見られるが, このトレンドを差し引いても，ス タッキング波形での検知日時は 27 日 17 時で, 個別観測 点より 6 時間早く検知できる結果となった。

次に, 各グリッドにすべりのソースがあったと仮定し た時のスタッキング波形から得られる情報について述べ る. Fig. 11は, (1)〜6のそれぞれにすべりを仮定した 時のスタッキング波形を示したものである. (4)と（5)の波 形に大きな正の方向 (上向き) への変化がみられること から、このグリッドですべりがあったことが推定され る、また(4)と(5)のそれぞれのスタッキング波形を比べる と, 明瞭に変化している時期は(4)の方が早いので, 短期 的 SSE は(4)から(5)へ移動したと推測される。これは低 周波地震の発生場所が(4)の領域から(5)の領域に移ってい ること (Fig. 9 (c)) と符合する.

しかし, ここで注意したいのは, 低周波地震が発生し ていない(3に拈いても27 日頃から若干の変化が見られ ること，また(1)，(2)，(6)では負の方向（下向き）の変化 が現れていることである。これらは，実際には(4)あるい は(5)ですべりが生じたのに，(1)〜 (3)，(6)すずりがあっ たと仮定してスタッキングしたときに現れる幻影であ る.このことについては, 第 5 章で改めて考察する.

すべりの発生は, (4)では 7 月 27 日から 29 日（Fig. 11 の period-1), (5)では 7 月 29 日から 31 日 (period-2) と見 てとれ，それぞれのスタッキング波形の変化量の読み取 り值から (9) 式を用いてすべりのモーメント量を推定す ると, (4)で $1.1 \times 10^{17} \mathrm{Nm}$, また(5)では $2.0 \times 10^{17} \mathrm{Nm}$ と求 

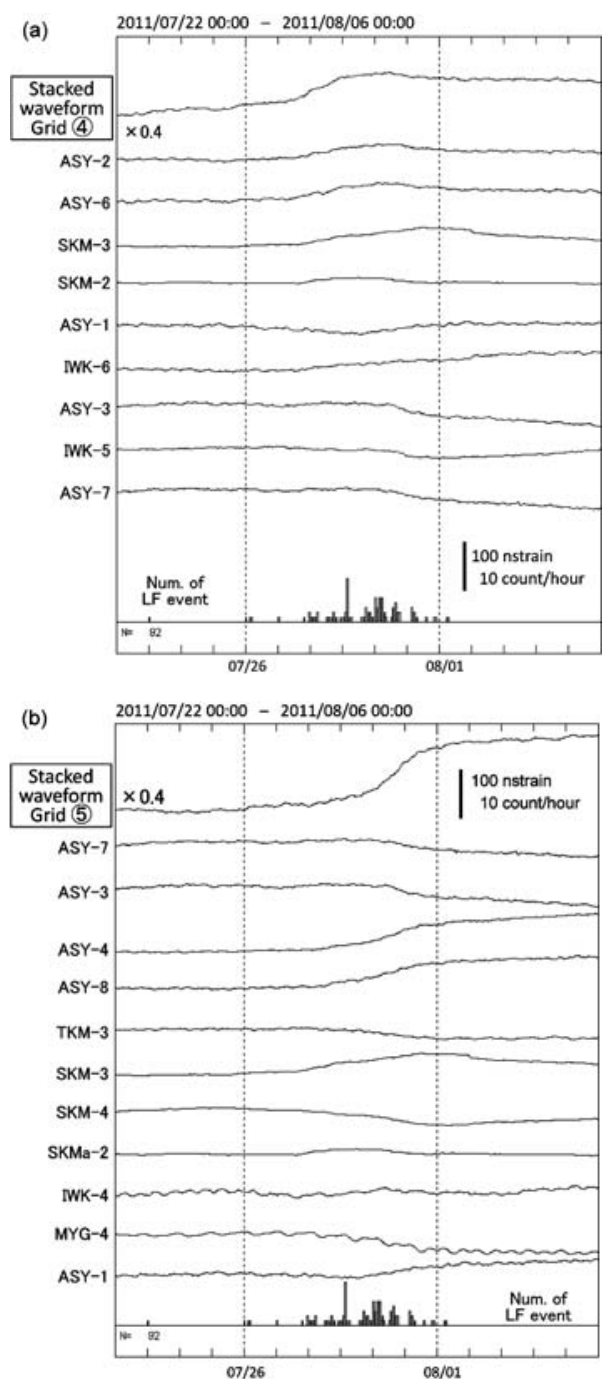

Fig. 10. Waveform at each observation station used in the stacking procedure and the stacked waveform (the top trace) when a slow slip event is supposed to occur at a grid point (a) 4 or (b) 5 in Fig. 9. Bars in the bottom line show number of low-frequency earthquakes.

まる。これを $M_{\mathrm{w}}$ に換算すると, それぞれ 5.3, 5.5 程度 となる. 気象庁 (2011b) は, 中村・竹中 (2004) の方法を 用い, 7 月 26 から 29 日と 7 月 30 から 31 日の 2 期間の ひずみ変化量から，それぞれのすべりの規模を $M_{\mathrm{w}} 5.3$ および 5.4 と推定している. 気象庁による解析とは期間 の分け方が若干異なるものの, スタッキング波形の変化 量から推定された $M_{\mathrm{w}}$ は両者でよく一致している.

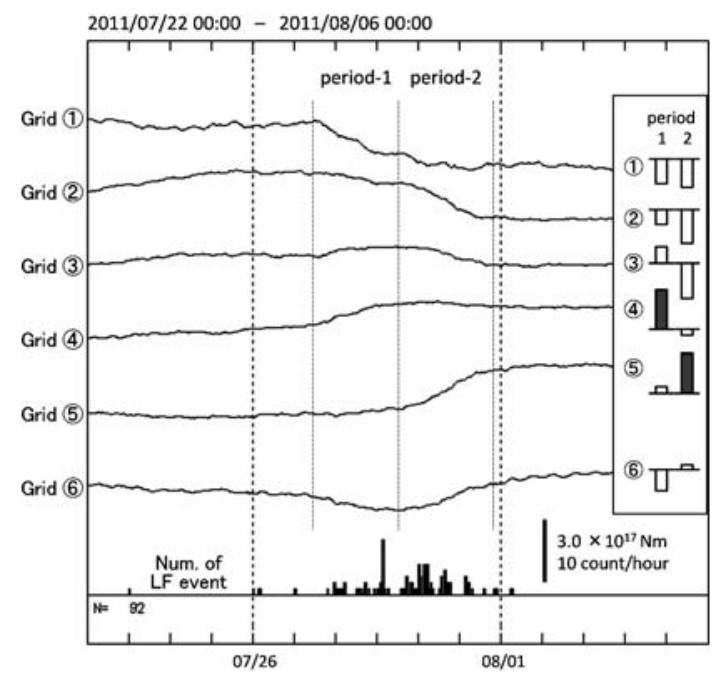

Fig. 11. Stacked waveforms obtained by assuming that a slow slip occurs at grid points 1 to 6 for the case shown in Fig. 10. Bars in the bottom line show number of low-frequency events. Black and white bars in the right panel show amplitudes and polarities of the stacked waveform at each grid point, where black bars in the panel indicate that the source is actually located at grid point 4 (period-1) and at 5 (period-2).

\section{§. 考察}

本章では，スタッキング法を適用するにあたって考慮 しておくべき注意点などについて考察する。

\section{1 スタッキング波形によるすべり位置推定}

すべり位置推定にあたって，観測網が十分でなかった り，観測点配置が偏っていたりすることによって，実際 にはすべっていないポイントにもソースがあるように見 える場合がある.Fig. 11 に示した例は，第 4 章で調べ た短期的 SSE の場合であるが，(4)，(5)でのすべりによっ て(1)〜 (3)，(6)にすべりを仮定してスタッキングした波形 に見かけ上の変化が現れている。 しかしこの例の場合で も, (4)もしくは(5)でのすべりに対して, 他のグリッドで すべりがあったと想定してスタッキングした波形（1) (3), (6)）にどのような変化が現れるかを予め調べておけ ば, そこで本当にすべりがあったかどうかの判断が可能 である。

Fig. 11 の右端には, (4)あるいは(5)ですべりが生じた 時に, 他のグリッドでのスタッキング波形に現れる変化 量（モーメント換算）の相対比を棒グラフで示した. こ れを見るとFig. 11の事例において, period-1 (7/27〜 7/29)に見られている各グリッドでのスタッキング波形 の変化の極性および変化量の大小関係は, (4)ですべりが 


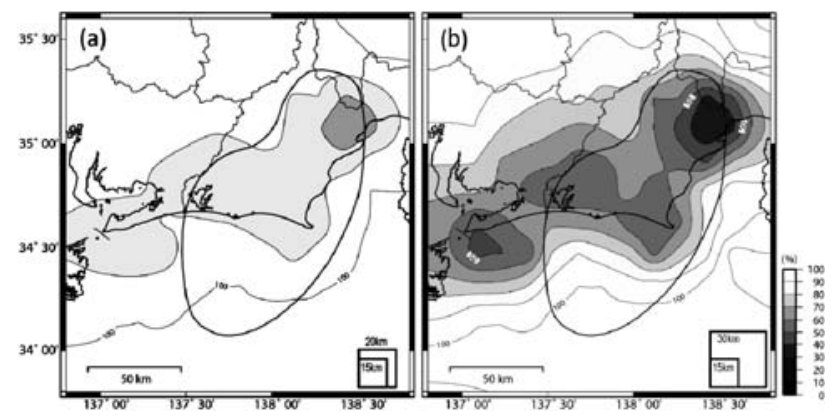

Fig. 12. Reduction of the amplitude of the stacked waveform when an incorrect source dimension is assumed. (a) A case that a source fault with $15 \mathrm{~km} \times 15 \mathrm{~km}$ is assumed when the actual source dimension is $20 \mathrm{~km} \times 20 \mathrm{~km}$. (b) Same as (a) except that the actual source dimension is $30 \mathrm{~km} \times 30 \mathrm{~km}$.

あった場合と，また period-2 (7/29〜7/31) は(5)ですべり があった場合とそれぞれ，概ね整合している。これらの ことから(1)〜 (3), (6)の点について, そのスタッキング波 形に見られる変化は, (4)およ゙拉に㧍けるすべりの幻影 であると判断することができる，なお，幻影が縮み方向 （一方向）の変化を示すのは，そこですべりが生じたと した場合の極性を基にスタッキングしているからであ る、したがって，本来，そこですべりがあれば，スタッ キング波形は必ず十方向の変化を示すはずで, 一方向の 変化が見られるということからして，直ちに，実際には そこですべりはないと判断することもできる。

\section{2 仮定する断層サイズについて}

スタッキング波形に現れる異常変化は，仮定したすべ り領域の位置や広がりが実際のすべり領域と一致した場 合に最も大きくなると期待され，それらが異なっていた 場合にはスタッキングする際の極性が反転して, SN 比 の向上が期待できないこともありうる，このため，仮定 した断層の広がりと著しく異なる範囲ですべりが発生し た場合の、スタッキング波形の変化量の違いを見積もっ ておくことが必要である。 そこで Fig. 9 の各グリッド点 に長さと幅が $15 \mathrm{~km}$ の断層の他に，それぞれが $20 \mathrm{~km}$, $30 \mathrm{~km}$ の断層を仮定し，いずれも $M_{\mathrm{w}} 5.0$ 相当のすべり を与えた場合に観測されるスタッキング波形での変化量 を計算した．各グリッドに扮ける $15 \mathrm{~km}$ 四方の断層の 場合の変化量に対する, $20 \mathrm{~km}$ 四方の断層での変化量の 比を求め，その分布を示したものが Fig. 12a である. 15 $\mathrm{km}$ 四方を想定したスタッキング波形によるモニタリン グで，実際には $20 \mathrm{~km}$ 四方の断層がすべった場合，全 体的に変化量は小さくなり, SN 比が 10 20\% 程度低下 することがわかる．同様に，Fig. $12 \mathrm{~b}$ には $15 \mathrm{~km}$ 四方の 断層を想定したモニタリングで, $30 \mathrm{~km}$ 四方の断層がす べった場合の変化量の比を示した。この場合，違いはさ
らに大きくなり, 想定震源域の北東端では, 変化量が半 分から $1 / 3$ 程度に低下するグリッドもある。このような ことから，実際に生じているすべりに応じた適切な断層 モデル（広がり）を仮定しないと，スタッキングの効果 は薄れることになる。

東海地域から四国地方の領域で観測されている短期的 SSEについては, イベント発生毎に断層モデルが解析 されている [例えば Hirose and Obara (2006), 産業技術 総合研究所 (2012)].これらの SSE の規模は $M_{\mathrm{w}} 5.5$ ない し 6.0 程度だが, 断層の広がりは $20 \mathrm{~km} \sim 50 \mathrm{~km}$ と, 同 規模の通常地震と比べて大きな值が推定されている。 た だし，本手法の主目的はゆっくりすべりの早期検知であ り, この観点からはイベント全体のすべり域をターゲッ 卜とする様な大きな断層を最初から設定しておくことは 適当でなく，すべり始めの変化を捉えるために想定する 断層の大きさとしては, $10 \mathrm{~km}$ ないし $15 \mathrm{~km}$ 程度が適当 と考えている.

しかし，本手法をゆっくりすべりの早期検知に，より 広汎に活用するためには, 予め数多くの断層モデルを設 定しておくことが望ましい，そのためには，すべりの位 置と広がりのそれぞれについて複数の組み合わせでのス タッキング波形を準備しておく必要がある.

\section{3 今後にむけて}

本論では，ひずみ計データでのスタッキング法の有効 性を示すにあたって, 東海地域のフィリピン海プレート 上面で発生するゆっくりすべりに適用した場合を考察し た。しかし本手法はひずみ計のみならず，傾斜計や GNSS といった他種の観測デー夕にも適用できると考え ている。.また東海地域や四国西部で発生している長期的 SSE, 火山体に㧍ける地款変動検出など, 異なる時間・ 空間スケールでの現象にも応用できると考えられる， 


\section{§6. ま と め}

ボアホールタイプのひずみ計の多点の波形データをス タッキングすることによって SN 比を大きくし，プレー 卜境界面上で発生するすべりの検知能力を向上させる手 法を開発した。

本手法のポイントは, 次の通りである。まず, プレー 卜境界面上にすべりを仮定し, 各観測点でのひずみ変化 を計算する. 反対の極性の変化が生じる観測点について はデータの極性を反転させ, 全ての観測点での変化の極 性を合わせる. SN 比の大きな観測点から順に波形をス タッキングし, その総合 SN 比が極大となる組合せ（観 測点数）を選び出す.

本論では, このスタッキング法を, 東海地震の想定震 源域周辺でのフィリピン海プレート上面でのすべりの検 出に適用して, 検知能力が以下のように改善されること を示した。

・SN 比は 2.3 倍に向上する

・ 24 時間あたりの変化量が $M_{\mathrm{w}}$ 換算で 5.0 より小さな プレートすベりが検出可能となる

・従来の手法に比べ, $M_{\mathrm{w}}$ 換算で 0.3 程度改善される

また本手法では, 波形の変化量のモニタリングによ り, すべり位置や規模について, その概要を容易に推定 することが可能である.

本手法はひずみ計デー夕に限らず，傾斜計や GPS デー夕を用いた解析にも適用できると考えており，より 多くの観測デー夕を用いるなら検知能力はさらに向上す るはずである。また，検出対象として，長期的 SSEや 火山体での変動源推定などにも応用できると考えている.

\section{謝辞}

本稿をまとめるにあたり, 温泉地学研究所長の吉田明 夫氏には多大なご指導をいただきました。査読者の板場 智史氏およびもう一人の匿名の査読者, 編集委員である 安藤亮輔氏には有益なご助言をいただきました。また国 土地理院の木村久夫氏, 気象庁の長谷川浩氏にはデー夕 解析にあたり，ご助力をいただきました。ここに記して 感謝申し上げます。一部の図の作成には GMT [Wessel and Smith (1998)] を使用しています。

\section{文献}

Heki, K. and S. Miyazaki, 2001, Plate convergence and long-term crustal deformation in central Japan, Geophys. Res. Lett., 28, 2313-2316.

Hirose, F., J. Nakajima, and A. Hasegawa, 2008, Threedimensional seismic velocity structure and configuration of the Philippine Sea slab in southwestern Japan estimated by double-difference tomography, J. Geo- phys. Res., 113, B09315, doi:10.1029/2007JB005274.

Hirose, H. and K. Obara, 2006, Short-term slow slip and correlated tremor episodes in the Tokai region, central Japan, Geophys. Res. Lett., 33, L17311, doi:10.1029/ 2006GL026579.

檜皮久義 - 佐藤 馨 - 二瓶信一 - 福留篤男 - 竹内 新 古屋逸夫, 1983, 埋込式体積歪計の気圧補正, 験震時 報，47，91-111.

石垣祐三, 1995, 埋达式体積歪デー夕の精密補正及び異 常識別について，験震時報，59, 7-29.

石黒真木夫・佐藤忠弘・田村良明 - 大江昌嗣, 1984, 地 球潮汐デー夕解析一プログラム BAYTAP-G の紹介一, 統計数理研究所彙報, 32, 71-85.

板場智史・松本則夫 - 北川有一 - 小泉尚嗣 - 木村武志 木村尚紀・廣瀬 仁・針生義勝, 2011, 歪・傾斜統合 解析による短期的 SSE 断層モデルの推定, 日本地震 学会予稿集, C31-05.

上垣内 修 - 束田進也, 2006, 気象庁の東海地震短期直 前予知戦略と新たな情報体系, 地震 $2, \quad 59,61-67$.

上垣内 修 - 内藤宏人 - 山本剛靖 - 吉川澄夫 - 小久保一 哉・宮岡一樹, 1999, 気象庁石井式歪計の応答特性解 析, 日本地震学会予稿集, B72.

加藤尚之・平澤朋郎, 1996 , 仮想東海地震に先行する非 地震性すべりと地殼変動の予測, 月刊地球号外, 14, 126-132.

気象庁，2010, 歪計による短期的スロースリップイベン 卜の検知について, 地震予知連絡会報, 84, 560-564.

気象庁, 2011a, 「東海地震に関連する情報」が新しくな ります，気象庁報道発表資料，平成 23 年 3 月 24 日。

気象庁，2011b，7月 26 日頃からの愛知県における深部 低周波地震活動に伴うひずみ変化，第 304 回地震防災 対策強化地域判定会資料,

小林昭夫・松森敏幸, 1999, 埋込式体積歪計のノイズレ ベル調査及び異常監視処理，験震時報，62，17-41.

Kobayashi, A., A. Yoshida, T. Yamamoto, and H. Takayama, 2005, Slow slip in the focal region of the anticipated Tokai earthquake following the seismo-volcanic event in the northern Izu Islands in 2000, Earth Planets Space, 57, 507-513.

小林昭夫・山本剛靖・中村浩二・木村一洋, 2006, 歪計 により観測された東海地域の短期的スロースリップ (1984 2005 年), 地震 2, 59, 19-27.

Kuroki, H., H. Itoh, and A. Yoshida, 2002, A threedimensional simulation of crustal deformation accompanied by subduction in the Tokai region, central Japan, Phys. Earth Planets. Int., 132, 39-58.

宮岡一樹, 2011, 多成分歪計の地磁気補正, 験震時報, 74, 29-34.

中村浩二・竹中 順, 2004, 東海地方のプレート間すべ り推定ツールの開発, 験震時報, 68, 25-35.

布村明彦・横田 崇, 2003, より明らかになった想定東 海地震の姿, 月刊地球号外，41，166-176.

Obara, K., 2002, Nonvolcanic deep tremor associated with subduction in southwest Japan, Science, 296, 1679-1681.

Okada, Y., 1992, Internal deformation due to shear and tensile faults in a half-space, Bull. Seism. Soc. Am., 
82, 1018-1040.

Ozawa, S., M. Murakami, M. Kaidzu, T. Tada, T. Sagiya, Y. Hatanaka, H. Yarai, and T. Nishimura, 2002, Detection and monitoring of ongoing aseismic slip in the Tokai region, central Japan, Science, 298, 1009-1012. 産業技術総合研究所, 2012, 紀伊半島 四国の歪 - 傾 斜・地下水観測結果（2011 年 5 月～2011 年 10 月）, 地震予知連絡会会報, 87, 399-418.

末廣重二, 1979, 地殼変動連続観測と埋込式歪計 ( I ),
測候時報, 46, 9-25.

水藤 尚・小沢慎三郎, 2009, 東海地方の非定常地殼変 動一東海スロースリップと 2004 年紀伊半島南東沖の 地震の余効変動, 地震 2, 61, 113-135.

Wessel, P. and W.H.F. Smith, 1998, New improved version of the Generic Mapping Tools released, EOS Trans. AGU, 79, 579.

吉田明夫, 2001, 東海地震の予知を目指して, 地学雑誌, 110, 784-807. 